\title{
Kan grundtvigsk folkelighed eksporteres?
}

\section{Af Hellmut Toftdahl.}

Poul Engberg: Grundtvig mellem $\emptyset$ st og vest. Mellem Sofia og Ratio. 88 sider - 128 kr. Poul Kristensens forlag 1993.

Grundtvig som patriark, dvs. en landsfaderlig, karismatisk person, hvis visioner og håb giver livskraft til et helt folk. Norden som brobygger mellem Øst og Vest, fordi vi her i Norden ved, hvad sand folkelighed og reelt demokrati er, takket være Grundtvigs indsats. Grundtvigs forståelse af det kvindelige princips betydning, hvis ikke bevidstheden skal stivne i gold intellektualisme. Europa som noget langt mere omfattende end EF (EU). Såfremt disse temaer lyder interessante, så kan denne bog på det varmeste anbefales. Poul Engberg har skrevet en bog, der velskrevet og engageret behandler disse og meget mere i et åndshistorisk perspektiv, som er imponerende for en bog af denne størrelse.

Bogen er komponeret som et folkeligt oplysende essay, bestående af i det mindste tre foredrag over samme tema. Det bevirker, at man nogle gange synes, man har hørt en detalje før i et af bogens tidligere kapitler. Denne gentagelsesform fremmer imidlertid forståelsen, fordi detaljer bliver uddybet for hver gang. Læseren får, trods bogens begrænsede omfang, en ganske omfattende viden om forskellen mellem den ortodokse østkirke og den romersk-katolske kirke i vest. Det er en opsplitning i Europa, som jerntæppet kun var en nutidig manifestation af, og som vil bestå også efter murens fald, fordi opsplitningen har dybe kulturhistoriske årsager. Engberg karakteriserer forskellen ved de to begreber: Sofia og Ratio.

»Sofia«, kærligheden til visdom, hviler i sig selv. Dens kontemplative skuen, visioner og syner formidlet i det historisk-poetiske sprog er den bærende kraft i det ortodokse menneskes tankegang. Engberg påstår, at der bag kommunismen gennem hele Sovjethistorien lå et »andet Rusland «, dybt forankret i den græsk-ortodokse tradition og »den russiske folkesjæl«, et synspunkt som Jørgen Bukdahl forfægtede i bogen »Rusland bag Stalin«.

»Ratio« betyder fornuft, og den rationelle indstilling til tilværelsen har ligget til grund for Vesteuropas ekspansion økonomisk, kulturelt og politisk. Derfor er de vesteuropæiske ideologier formuleret i et pragmatisk, logisk sprog, der gør dem velegnede som grundlag for en målrettet, fremadstræbende og vækstorienteret kultur.

Overbevisende virker Engbergs argumentation for, at den marxistiske materialisme som en vestlig, intellektuel opfindelse var et fremmedelement påført det russiske folk af dets intellektuelle elites snobberi for Vesten. 
Engberg er tydeligt modstander af elitær kommunisme. Han er også modstander af unioner i såvel vest som øst, når disse presses ned over folkeslagene. EF (EU) og NATO er de store dyr i åbenbaringen, og de er Tysklands og katolicismens magtinstrumenter over for de østeuropæiske og nordiske lande. Hans vision er, som Herders og Grundtvigs, en humanitet praktiseret af frie, fredelige, demokratiske folkeslag som alternativ til de centraleuropæiske magtkoncentrationer: pavekirken og EU. De er en kirkelig og en verdslig manifestation af det samme elitære, centralistiske uvæsen.

Engberg harcellerer i bogens indledning polemisk mod Grundtvig-Selskabet: Vi har altid i videnskabelighedens navn interesseret os meget for, »hvad Grundtvig egentlig mente«, men for Poul Engberg er dette af mindre betydning. Grundtvigs virkningshistorie er langt mere betydningsfuld: »Hvad der fik den store betydning i vort folks liv og historie var ikke hans meninger, men hans visioner, som de banede sig vej tværs gennem al tidsbegrænsning, især ved hans digtes og salmers poetiske kraft, men også i hans poetiske prædikener og i den prosa, der ud fra historiens poesi kaster lys over folkenes og menneskehedens livsvilkår « (side 8). Engberg håber, at det norske Grundtvig-Selskab bedre end det danske har en sådan visionær forståelse for at kunne vejlede en grundtvigsk-folkelig bevægelse, thi det er alene »poesi og syner, der som et kvindeligt livselement kan vække et folk af dvale« (side 9). Og Engberg stiler højt med sin bog. Han forestiller sig, at »russisk folkelig og kristelig livsforståelse « kan berige Vestens rationalistiske livsssyn, og »denne berigelse bør kunne samvirke med de grundtvigske syner hos nordiske folk i samme grad, som der foreligger en åndsbeslægtethed«. Dermed kunne det historiske øjeblik indtræffe i vor europæiske verden, som Grundtvig drømte om ved 1800-tallets begyndelse: »at Norden kunne træde ind i den europæiske historie med sit folkelige budskab « (side 9). »Og kunne folkene $\mathrm{i}$ verden få øje på dette lys fra Norden og Østeuropa, ville en dybere livsforståelse kunne føre dem til større fordragelighed og gensidig agtelse« (side 10).

Det er store ord og dristigt tænkt, at de nordiske lande med Danmark i spidsen skulle kunne tilføre den europæiske virkelighed noget demokratisk værdifuldt. At Grundtvig mente dette, er velkendt. Også Martin A. Hansen var i »Leviathan « inde på en lignende forestilling om Dannevirke som bolværk mod den centraleuropæiske centralisme, og sidst har lignende formuleringer været fremme i Unionsdebatten. Der er da heller ingen tvivl om, at det danske nej til Maastrichtunionen har medvirket til at afsløre det demokratiske underskud i Unionskonstruktionen. At tolke den danske unionsmodstand som et resultat af Grundtvigs virkningshistorie er vel også foreneligt med, hvad Grundtvig »egentlig mente « om Frankrig, Tyskland og alskens pavedømme. Det såkaldte subsidiaritetsprincip eller nærhedsprincippet i EU: at toppen afgør, hvad bunden skal have lov til at bestemme, har 
intet med folkeligt demokrati at gøre. I et sådant er det bunden, der suverænt afgør, hvor meget toppen skal have lov at bestemme. Grundtvigs ideer om en sådan demokratisk selvforvaltning, demokrati fra neden, var progressive og er det altså stadigvæk i europæisk sammenhæng. At give Grundtvigs folkelighedsbegreb del i æren af den danske unionsskepsis er således ikke blot sagligt forsvarligt, men også nødvendigt for en forståelse af den betydning, Grundtvigs virkningshistorie har haft for danskernes folkelige demokratiopfattelse: retten til at gå på tværs af magthavernes interesser.

Mere usikker er jeg på Engbergs forhåbninger til de østeuropæiske folks muligheder i den aktuelle historiske situation. Siden Engberg skrev bogen, har vi set, hvorledes den russiske folkesjæl manifesterede sig ved det første frie parlamentsvalg: Halvdelen af vælgerne blev derhjemme, og næsten en fjerdedel stemte på den højreekstremistiske, nationalistiske Zirinovskijs parti. Mon ikke både Grundtvig og Herder i opfattelsen af folkesjælen var for meget præget af deres romantiske samtids idealisme til, at vi i dag kan dele deres tro på folkesjælens uspolerede oprindelighed. Jeg er bange for, at også Engberg har lidt for idealistiske forestillinger om den russiske folkesjæl. Jeg vil citere fra en kilde, der har nærmet sig begrebet folkesjæl fra en anden synsvinkel. Palle Juul Holm skriver (i »Ravheksen. Eventyr og andre folkelige fortællinger fra det $\emptyset$ stlige Europa«, Århus 1981, side 7): »Eventyr og sagn er en vigtig del af den folkelige fortælletradition, og at læse dem med lydhørhed er også en vej til at forstå de mennesker, der fortalte dem og lyttede til dem. Den folkelighed, de afspejler, er ikke ideel, men bred og reel, det vil sige en folkelighed på godt og ondt.« Den østeuropæiske folkesjæl, han læser sig frem til, afviger meget fra den Engbergske. Eventyrene afslører »humor, menneskelig varme og en lang række andre værdifulde egenskaber, men unægtelig også mere suspekte sider af den menneskelige natur: autoritetstro, sentimentalitet, foragt for de grimme og dumme, fremmedhad og hævntørst. Det ville i grunden også være naivt at forvente andet: den folkelige kultur er jo ikke bare det uplumrede kildevæld, det store kraftreservoir; den afspejler også undertrykkelsens virkelighed, bærer dens brændemærke« (sst. side 8). Med denne karakteristik af den østeuropæiske folkesjæl forstår man bedre, hvad det er for kræfter, der blev sluppet løs, da Sovjetstaten slap sit jerngreb om de mange etniske minoriteter i Østeuropa og Rusland. Engbergs forestillinger om den ortodokse kirkes betydning for det russiske folk er nok ikke helt realistiske, men det er da rigtigt, at Sovjetstyret på det sidste opgav forfølgelsen af kirken i håb om med kirkens hjælp at få styr på landets etniske problemer. Kun fremtiden kan vise, om det vil lykkes for kirken, hvad ikke engang Stalinismen formåede: at få de mange folkeslag til at fremstå som ét russisk folk. Jeg tvivler på, om det grundtvigske folkelighedsbegreb overhovedet kan anvendes på etniske problemer inden for landområder, som er meget større end det danske. På 
den måde havde Grundtvig nok ret $\mathrm{i}$, at Danmark var ideelt som demokratiets og folkelighedens vugge - mere i kraft af størrelsen end i kraft af nogen speciel nationalkarakter eller ideel folkesjæl. Det er slet ikke sikkert, at det formelle vestlige demokrati passer til den russiske folkesjæl. Ret beset er der vel egentlig heller ikke megen folkelighed eller »folkesjæl« aktiveret omkring en dansk folkeafstemning. Måske er det russiske folks demokratiske passivitet netop udtryk for en ærlig »folkesjæls « politikerlede og -træthed efter et halvt århundredes elitære unionsprojekter.

Engberg inddrager Dostojevski i bogen. Interessant ville det også have været at se Solsjenitsyn inddraget i diskussionen om den russiske folkesjæl. Siden bogen blev skrevet er han vendt hjem til sit fædreland som ortodoks patriot. Han har talt om behovet for »national anger«, og han har betegnet Zirinovskij som en »karrikatur af en patriot«. Også Vaclac Havel ville have været interessant $\mathrm{i}$ denne sammenhæng som eksempel på en østeuropæisk politiker, der har forsøgt at formulere en mere Sofia-præget opfattelse af Europas nuværende politiske problemer.

Så meget om Engbergs aktuelle politiske visioner. Hans placering af Grundtvig som et bindeled mellem Øst og Vest i kirkelig henseende er en anden side af bogen, som selvfølgelig heller ikke kan løsrives fra den aktuelle politiske virkelighed, da den europæiske deling har dybe rødder i den religiøse virkelighed. At Grundtvig var inspireret af Østkirken har både Kaj Thaning, Thodberg, Uffe Hansen og Niels Thomsen vist, og Engberg angiver dem også som sine kilder. Jeg mener dog, at der var mere ratio, dvs. intellektuel analyse og distance i Grundtvigs opfattelse af billeder og symboler, end Engberg får frem. Det var uenighed om symbolet, afbildningen, der førte til delingen mellem Østkirken og den romersk-katolske, da kejser Leo III i 726 forbød dyrkelse af billeder. Grundtvig er gammeltestamentlig i sin opfattelse af billeddyrkelse, deraf hans modvilje mod bildende kunst: »Når skyggen er ligest, da hulke de små, som stirrer derpå«. Der er derfor noget paradoksalt $i$, at få som han har dyrket billedet, symbolet, i sin kunst, og hans Dannevirke-afhandlinger viser da også, hvilke intellektuelle overvejelser han har måttet igennem for at legitimere denne billedskabende æstetiske praksis. Hans brug af symbolet peger derfor ikke bare bagud til den ortodokse kirke, men også (og unægteligt mere relevant for danske forhold) fremad til f.eks. Sophus Claussens symbolisme, ekspressionismen og modernismen. I den Grundtvigske symbolverdens indkredsen af fællesmenneskelige forestillinger og $\mathrm{i}$ hans tro på symbolets forløsende effekt er der også ligheder med Jungs teorier om symboler. Men Jung var jo også inspireret af folkeeventyr og sagn, dvs. visdom, Sofia, og dermed er vi atter tilbage ved Engbergs udgangspunkt. Jeg vil hermed blot antyde, at Engbergs placering af Grundtvig i en øst-vest problematik nok er sandsynlig og anvendelig for den aktuelle politiske perspektivering, som er Engbergs 
ærinde, men at det bestemt ikke er den fulde sandhed om Grundtvigs ejendommelige brug af billedsprog. "Grundtvig ikke alene skriver symbolistisk-ekspressionistisk, men ser også sig selv og sin samlede virksomhed som et symbol«, skriver Fl. Lundgreen-Nielsen i »Det handlende ord «, II, side 888. "Endnu i en tid, der var langt mere vejende, målende og tællende...måtte Freud og Jung ty til billeder og modeller for at anskueliggøre deres opfattelse af den usynlige åndelige virkelighed i menneskets indre« (sst. s.887).

Betænkeligheder og indvendinger til trods er det en fornøjelse at læse en bog, der behandler det moderne Europas situation i et åndshistorisk perspektiv. Hvis ikke man vidste det før, så ved man efter læsning af Engbergs bog, at der er langt større kræfter på spil i dagens Europa, end dem der udtrykkes i politiske og markedsøkonomiske termer. At Grundtvig har anet disse kræfters tilstedeværelse som konstante faktorer i Europas historie, og at han derfor stadig kan have noget væsentligt at sige om forskellen på folkelighed og nationalisme, patriotisme og racisme, folkelig vækkelse og politisk opinionsdannelse, det er man ikke i tvivl om efter læsning af denne bog.

\title{
Nornesalen - forskning i spændingsfeltet mellem akademisk tradition og folkelig aktualitet
}

\author{
Af Kim Arne Pedersen
}

Nornesalen. Forskning 1992-1993. Ringe 1993. Lilian Zфllner (red.): Almen Dannelse Folkelig Dannelse Folkelig Livsoplysning. Vejle 1993.

Det er med en vis forventning, man sætter sig til at læse de to bøger, der her skal anmeldes. Forventningerne skyldes, at der er tale om henholdsvis det første årsskrift og den første egentlige udgivelse fra en ny og utraditionel videnskabelig institution, det i 1992 indviede "Nornesalen Forskningscenter for folkelig livsoplysning «. Dette forskningscenter hører under Kulturministeriet og er knyttet til Biblioteket for det Folkelige arbejde, som i 1985 oprettedes af repræsentanter for Den frie lærerskole, Foreningen for folkehøjskoler i Danmark, Dansk Friskoleforening, Foreningen af Frie Ungdomsog Efterskoler og De danske Gymnastik- og ungdomsforeninger. Såvel bibliotek som forskningscenter er beliggende på Den frie Lærerskole i Ollerup. En drivende kraft $\mathrm{i}$ arbejdet med etableringen af det nævnte bibliotek, der fungerer som landsarkiv for de folkelige bevægelser, var afdøde fhv. fri- 